\title{
Neuritogenic effect of standardized extract of Centella asiatica ECa233 on human neuroblastoma cells
}

\author{
Oraphan Wanakhachornkrai ${ }^{1}$, Varisa Pongrakhananon ${ }^{2,3}$, Preedakorn Chunhacha ${ }^{3}$, Aree Wanasuntronwong ${ }^{4}$, \\ Anusara Vattanajun ${ }^{5}$, Boonyong Tantisira ${ }^{2,6}$, Pithi Chanvorachote ${ }^{2,3^{*}}$ and Mayuree H Tantisira ${ }^{2,7^{*}}$
}

\begin{abstract}
Background: In order to gain insight into neuroprotective effects of ECa 233, a standardized extract of Centella asiatica, previously demonstrated in animal models of memory impairment induced by transient global ischemia or intracerebroventricular injection of $\beta$-amyloid, the effect of ECa 233 on neurite outgrowth of human IMR-32 neuroblastoma cell line was investigated.

Methods: Cells were seeded and incubated with various concentrations of ECa 233. Morphometric analysis was carried out by a measurement of the longest neurite growth of cells at 24 and $48 \mathrm{~h}$. Contributing signaling pathways possibly involved were subsequently elucidated by western blot analysis.

Results: While ECa 233 had only limited effects on cell viability, it significantly enhanced neurite outgrowth of IMR32 cells at the concentrations of $1-100 \mu \mathrm{g} / \mathrm{ml}$. Western blot analysis revealed that ECa 233 significantly upregulated the level of activated ERK1/2 and Akt of the treated cells suggesting their involvement in the neuritogenic effect observed, which was subsequently verified by the finding that an addition of their respective inhibitors could reverse the effect of ECa 233 on these cells.

Conclusions: The present study clearly demonstrated neurite outgrowth promoting activity of ECa 233. ERK1/2 and Akt signaling pathways seemed to account for the neurotrophic effect observed. In conjunction with in vivo neuroprotective effect of ECa 233 previously reported, the results obtained support further development of ECa 233 for clinical use in neuronal injury or neurodegenerative diseases.
\end{abstract}

Keywords: Neurite outgrowth, Centella asiatica, ECa 233, ERK1/2, Akt, IMR-32 neuroblastoma

\section{Background}

Neurite outgrowth is an important initial step in the formation of neuronal network. Such neuronal behavior was also shown to implicate in neuronal regeneration and response to neural injury [1]. Mechanisms in regulation of neurite outgrowth have been intensively investigated and the most accepted concept involves MEK/ ERK and PI3K/Akt signaling pathways. Indeed, these molecular signals are triggered by tyrosine kinase receptor activation [2-6]. Several neurotrophic ligands for

\footnotetext{
* Correspondence: pithi_chan@yahoo.com; tmayuree@chula.ac.th ${ }^{2}$ Department of Pharmacology and Physiology, Faculty of Pharmaceutical Sciences, Chulalongkorn University, Bangkok 10330, Thailand

${ }^{3}$ Cell-based Drug and Health Product Development Research Unit,

Chulalongkorn University, Bangkok 10330, Thailand

Full list of author information is available at the end of the article
}

tyrosine kinase receptors such as nerve growth factor (NGF), brain derived neurotrophic factor (BDNF) and neurotrophin-3 (NT-3) have been identified $[7,8]$. The activation of MEK/ERK and PI3K/Akt results in an increase in cell survival as well as an enhancement of neuronal growth and differentiation $[9,10]$. In this context, molecules or compounds that exhibit potent neurotrophic activity are of great interest and may be useful for the treatment of stroke, brain or spinal cord injury and neurodegenerative diseases [11-13].

In search for potential neurotrophic activity from herbs acting on the central nervous system, the present study focused on the neurotrophic activity of Centella asiatica which has, for a long time, been claimed to be beneficial for managing disorders of the brain, skin and 
gastrointestinal tract [14]. Additionally, it was used as a brain booster for promoting brain growth and improving memory [12]. Like many other medicinal plants, $C$. asiatica contains several active compounds, including asiatic acid, madecassic acid, asiaticoside, and madecassoside [15]. To avoid a large fluctuation in biological responses arising from variations of these bioactive constituents, we have established the standardized extract of C. asiatica, namely ECa 233. It is defined as a white to off-white extracted powder of $C$. asiatica containing triterpenoids not less than $80 \%$ and the ratio between madecassoside and asiaticoside was kept within $1.5 \pm 0.5$ [16]. Restorative and neuroprotective effects of ECa 233 have been demonstrated in animal models of learning and memory deficit induced by either a transient occlusion of common carotid arteries [17] or an intracerebroventricular injection of $\beta$-amyloid [18]. Protection of oxidative stress was proposed to be one of the possible underlying mechanisms. However, effect of ECa 233 on neurite outgrowth which could possibly be involved in its neurotrophic/neuroprotective effects has not yet been elucidated. Therefore, the present study aimed to investigate the effect of ECa 233 on the neurite growth and its underlying mechanisms in IMR-32 human neuroblastoma cells.

\section{Methods}

\section{Cell culture and reagents}

IMR-32 neuroblastoma cells were obtained from the American Type Culture Collection, ATCC (Manassas, VA, USA). Cells were cultured in DMEM/F12 supplemented with $10 \%$ fetal bovine serum, $2 \mathrm{mmol} / \mathrm{l} \mathrm{L}$-glutamine and 100 units/ml penicillin/streptomycin in a $5 \%$ $\mathrm{CO}_{2}$ at $37^{\circ} \mathrm{C}$. BDNF, PD 098059, LY 294002 were purchased from Sigma Chemical. Inc. (St. Louis, MO, USA). Resazurin was purchased from Invitrogen (Carlsbad, CA, USA). Specific antibody for phospho-Akt, Akt, phospho-ERK1/2, ERK1/2 and GAPDH were purchased from Abcam (Cambridge, MA, USA), and peroxidase conjugated anti-rabbit secondary antibody were purchased from Cell Signaling (Danvers, MA, USA).

\section{Preparation of tested substances}

ECa 233 containing madecassoside 52\% w/w and asiaticoside $32 \% \mathrm{w} / \mathrm{w}$ was kindly supplied by Associate Professor Ekarin Saifah, Ph.D and collaborates, Faculty of Pharmaceutical Sciences, Chulalongkorn University. Thailand. It was suspended in sterile PBS at $10 \mathrm{mg} / \mathrm{ml}$ and served as stock solution. BDNF was dissolved in the sterile PBS to a stock solution at the concentration of $50 \mu \mathrm{g} / \mathrm{ml}$. PD098059 and LY294002 were dissolved by DMSO to concentration of 0.344 and $0.267 \mathrm{mg} / \mathrm{ml}$, respectively.

\section{Cell viability assay}

Cells were seeded in 96-well plates and incubated for $24 \mathrm{~h}$. After incubation, the plating media were removed and replaced. The cell were subsequently incubated for 30 minutes then subjected to treatments. After $24 \mathrm{~h}$, cells were incubated with 1:50 resazurin at $37^{\circ} \mathrm{C}$ for 30 minutes. The well-plate was transferred to a fluorescence microplate reader with Softmax Pro software to measure fluorescence intensity of resorufin (resazurin product) at excitation wavelength of $530 \mathrm{~nm}$ and emission wavelength of $590 \mathrm{~nm}$. The percentage of cell viability was calculated and compared with non-treated control. All analyses were performed for at least three independent triplicate experiments.

\section{Measurement of neurite outgrowth}

IMR-32 cells were cultured in a 96-well culture plate. After $24 \mathrm{~h}$ cells were subjected to various concentrations of ECa $233(0.1,1,10,100 \mu \mathrm{g} / \mathrm{ml})$ or BDNF $(100 \mathrm{ng} / \mathrm{ml})$. A neurite was identified as a process equal to or longer than cell body diameter. The cells selected randomly from 3-4 fields of each well were photographed (phase contrast, Nikon, Inverted microscope ECLIPSE Ti-u) for morphometric analyses. The length of the longest neurite from each cell was measured using NIS-Element image software $[19,20]$.

To test the involvement of MEK and Akt pathway, their respective inhibitors, PD098059 (5 $\mu \mathrm{M})$ for MEK and LY294002 $(7.5 \mu \mathrm{M})$ for PI3K/Akt, was added at $30 \mathrm{~min}$ prior to the test substance.

\section{Western blot analysis}

After specified treatments, cells were incubated in lysis buffer containing $20 \mathrm{mM}$ Tris- $\mathrm{HCl}$ (pH 7.5), 1\% TritonX-100, $150 \mathrm{mM}$ sodium chloride, 10\% glycerol, $1 \mathrm{mM}$ sodium orthovanadate, $50 \mathrm{mM}$ sodium fluoride, $100 \mathrm{nM}$ phenylmethylsulfonyl fluoride, and a commercial protease inhibitor cocktail (Roche Molecular Biochemicals, Indianapolis, IN, USA) for 30 minutes on ice. Cell lysates were collected and centrifuged 12,000 rpm at $4^{\circ} \mathrm{C}$, the supernatant was collected and the protein content was determined using Bradford method (BioRad, Hercules, CA, USA). Equal amount of proteins from each sample were denatured by heating at $95^{\circ} \mathrm{C}$ with laemmli loading buffer for $5 \mathrm{~min}$ and were subsequently loaded onto $10 \%$ SDS-PAGE. After separation, proteins were transferred onto $0.45 \mu \mathrm{m}$ nitrocellulose membranes (Bio-Rad). The transferred membranes were blocked in 5\% non-fat dry milk in TBST (25 mM Tris$\mathrm{HCl}$ (pH 7.5), $125 \mathrm{mM} \mathrm{NaCl}, 0.1 \%$ tween20) for $1 \mathrm{~h}$. Then washed with TBST and further incubated with the indicated primary antibodies at $4^{\circ} \mathrm{C}$ overnight. Membrane were washed twice with TBST for $10 \mathrm{~min}$ and incubated with secondary antibody for $1 \mathrm{~h}$ at room 
temperature. The immune complexes were detected by enhanced chemiluminescence substrate (Supersignal West Pico; Pierce, Rockford, IL, USA) and quantified using Image J software.

\section{Data analysis}

The results are expressed as mean \pm S.D. or S.E. Simple comparison between two groups was performed using $t$-test. Comparison of data between groups was performed using one-way ANOVA follow by Tukey's post hoc test. $P<0.05$ was considered statistically significant.

\section{Results}

\section{Effect of ECa 233 on viability of IMR-32 cells}

First, effect of ECa 233 on cell viability of IMR-32 cells was determined using Resazurin based assay. Cells were incubated in the presence or absence of ECa $233(0.1,1$, 10 and $100 \mu \mathrm{g} / \mathrm{ml}$ ) for 24 and $48 \mathrm{~h}$ and percentage of cell viability was determined. Percentage of such cell viability was compared among groups as well as with non-treated control $(\mathrm{p}<0.05)$ (Figure 1). The results show that cell viability was $106 \pm 1.6,95.6 \pm 6.44,102.4 \pm 4.03$ and $104.6 \pm$ $7.48 \%$ of control in response to ECa 233 at the concentrations of $0.1,1,10$ and $100 \mu \mathrm{g} / \mathrm{ml}$, respectively. In addition, cell viability at $48 \mathrm{~h}$ after treatment in all ECa 233-treated groups showed no significant change from that of nontreated control indicating that treatment with ECa 233 at the concentrations tested had neither cytotoxic nor proliferative effects on these neuroblastoma cells.

\section{Neuritogenic activity of ECa 233 on neurite outgrowth}

The non-cytotoxic and non-proliferative concentrations of ECa 233 at $0.1,1,10$ and $100 \mu \mathrm{g} / \mathrm{ml}$ were further used in neurite outgrowth experiments. BDNF, a well-known trophic factor of neurite extension and neuronal survival was used as a positive control. We found that the addition of $100 \mathrm{ng} / \mathrm{ml} \mathrm{BDNF}$ to the cells caused dramatic increase of the neurite outgrowth (Figure 2B). Likewise, cells

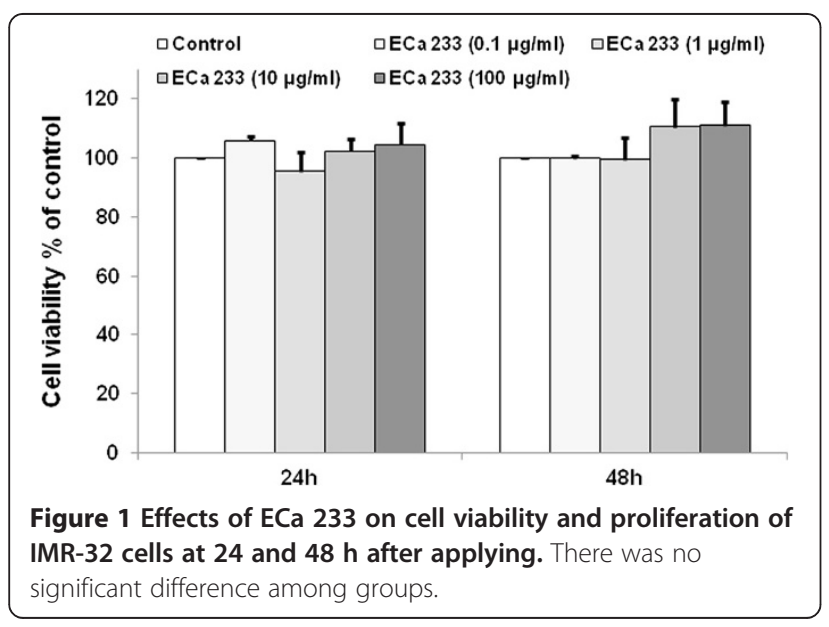

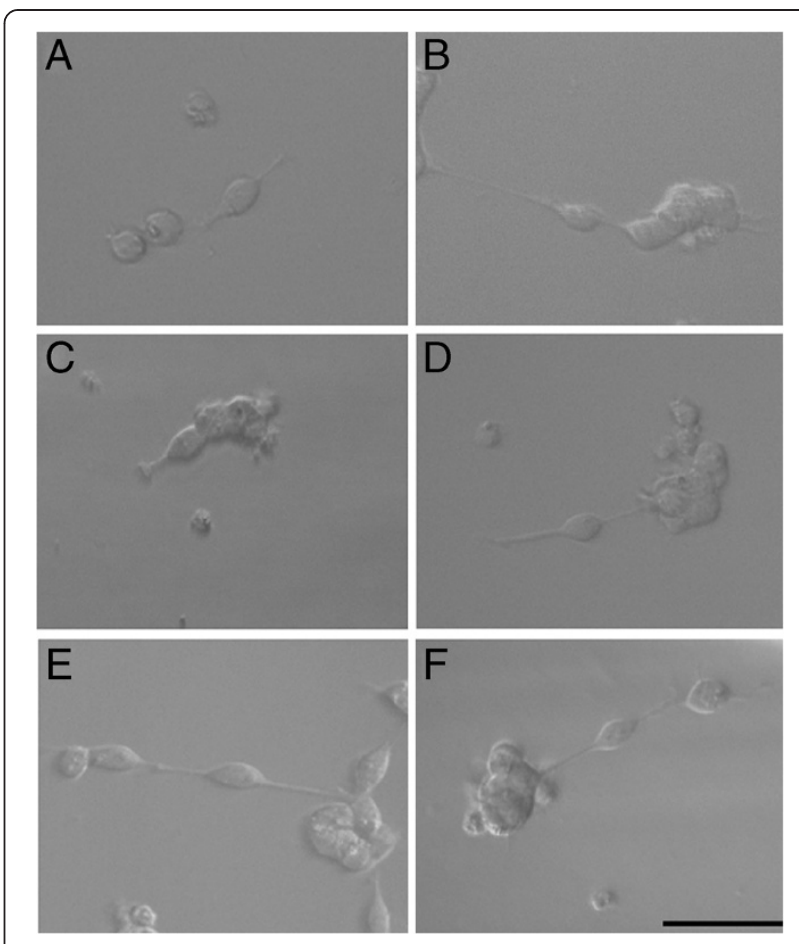

Figure 2 Representative photomicrograph of IMR-32 cells using phase contrast. (A) non-treated control, (B) BDNF $100 \mathrm{ng} / \mathrm{ml}$, (C-F) ECa $2330.1,1,10$ and $100 \mu \mathrm{g} / \mathrm{ml}$ respectively (scale bar $=50 \mu \mathrm{m}$ ). Cells treated with BDNF and ECa 233 at the concentrations of 1, 10 and $100 \mathrm{\mu g} / \mathrm{ml}$ showed relatively longer neurite length.

treated with ECa 233 at the concentrations of 1, 10 and $100 \mu \mathrm{g} / \mathrm{ml}$ exhibited increased length of neurite compared to those of non-treated control (Figure 2D-F).

The morphometric analysis was carried out by measuring the longest neurite length per cell (Figure 3). After 24 and $48 \mathrm{~h}$ of treatment, the length of neurite obtain from cells treated with ECa 233 at the concentration of $0.1 \mu \mathrm{g} / \mathrm{ml}(23.02 \pm 1.05$ and $26.46 \pm 0.87 \mu \mathrm{m})$ was not significantly different from those of non-treated cells $(26.22 \pm 1.19,27.91 \pm 1.01 \mu \mathrm{m})$. Whereas, neurite lengths exposed to ECa 233 at the concentrations of 1, 10 and $100 \mu \mathrm{g} / \mathrm{ml}$ were significantly enhanced in a timedependent manner $(35.58 \pm 2.61,37.39 \pm 2.69$ and $39.9 \pm$ $2.73 \mu \mathrm{m}$ at $24 \mathrm{~h}$, and $47.57 \pm 2.84,44.03 \pm 1.66$ and $46.52 \pm 2.71 \mu \mathrm{m}$ at $48 \mathrm{~h})$. Similar results were obtained when the cell were treated with BDNF $100 \mathrm{ng} / \mathrm{ml}(35.83$ \pm 2.17 and $54.38 \pm 4.06 \mu \mathrm{m})$. Notably, the effect of ECa 233 at 1,10 and $100 \mu \mathrm{g} / \mathrm{ml}$ was comparable to that of BDNF with no significant difference.

\section{Possible mechanisms of ECa 233-mediated neuritogenic activity}

Effect of ECa 23 on ERK1/2 and Akt

In order to provide the possible mechanism of ECa 233mediated neurite outgrowth observed in IMR-32 cells, 

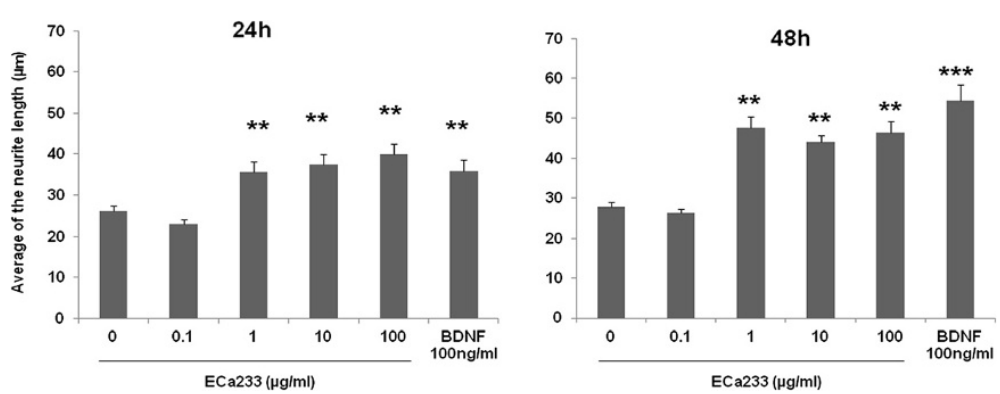

Figure 3 Morphometric analysis of IMR-32 cells affected by ECa 233. After cells cultured for 24 and $48 \mathrm{~h}$ in the presence of either ECa 233 $(0.1,1,10$ and $100 \mathrm{\mu g} / \mathrm{ml})$ or BDNF $(100 \mathrm{ng} / \mathrm{ml})$. Morphometric analysis was carried out by measuring neurites from 60 living cells per treated condition, $(n=3)$. Average of the neurite length was significantly increased after being treated with ECa $233(1,10 \mathrm{and} 100 \mu \mathrm{g} / \mathrm{ml}) \mathrm{or}$ BDNF. The data presented as mean \pm S.E. ${ }^{* *}=p<0.01,{ }^{* * *}=p<0.001$ vs non-treated control.

western blot analysis was carried out to determine whether ERK and Akt signaling were involved. Cells were treated with ECa 233 and the level of phosphorylated ERK and phosphorylated Akt were determined. Figures 4A and $\mathrm{B}$ demonstrated that relative blot density of pERK/ERK and pAkt/Akt in response to ECa 233 at the concentration of $0.1 \mu \mathrm{g} / \mathrm{ml}$ was not different from that of non-treated group. However, ECa 233 at the concentrations of 1,10 and $100 \mu \mathrm{g} / \mathrm{ml}$ significantly increased the level of phosphorylated ERK and phosphorylated Akt, suggesting that ECa 233 could possibly increase the neurite outgrowth via these 2 major pathways.

\section{Effect of ECa 233 on neurite outgrowth in the presence of PD098059 and LY294002}

Subsequently, the involvement of ERK and Akt signaling pathways in the neurite outgrowth promoting activity of ECa 233 was confirmed by treatment of specific inhibitor of MEK (PD098059) or PI3K (LY294002) prior to the exposure to ECa 233. In comparison to neurite lengths of non-treated group which was $23.39 \pm 0.54 \mu \mathrm{m}$ (Figure 5A), ECa 233 at the concentrations of 1, 10 and $100 \mu \mathrm{g} / \mathrm{ml}$ significantly enhanced the neurite outgrowth into $36.12 \pm 1.53,36.79 \pm 1.60$ and $36.69 \pm 1.98 \mu \mathrm{m}$ respectively. Pretreatment of the cell with PD098059 significantly decreased the neurite outgrowth of the respective concentrations of ECa 233 into $22.45 \pm 0.65$, $20.76 \pm 0.532$ and $21.83 \pm 0.53 \mu \mathrm{m}$. Similar results were demonstrated by LY294002 which significantly decreased the ECa 233-induced neurite outgrowth into $20.83 \pm$ $0.81,20.03 \pm 0.49$ and $20.76 \pm 0.53 \mu \mathrm{m}$, respectively (Figure 5B). As expected, PD098059 (5 $\mu \mathrm{M})$ or LY294002 $(7.5 \mu \mathrm{M})$ in the concentration that exhibited no significant effect on neurite outgrowth $(23.52 \pm 0.84$ and $20.43 \pm 0.54 \mu \mathrm{m}$, respectively) completely abolished neurite stimulating effect of ECa 233.
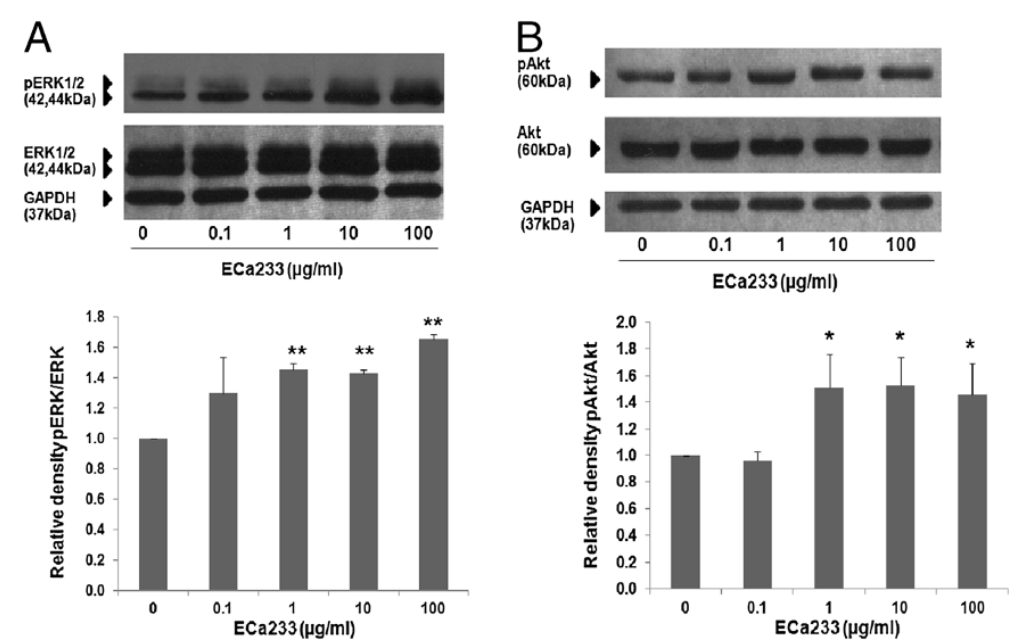

Figure 4 Relative blot density of pERK/ERK and pAkt/Akt in response to ECa 233 treatment. (A) ERK1/2 and ERK1/2 phosphorylation (B) Akt and Akt phosphorylation. The level of phospho-ERK1/2 and phospho-Akt in IMR-32 cells after treated with ECa $233(1,10 \mathrm{and} 100 \mathrm{\mu g} / \mathrm{ml})$ for $6 \mathrm{~h}$ were significantly higher than that of control. Densitometric analysis of the indicated proteins normalized with the density of GAPDH band were plated and presented as mean \pm S.D. of three independent experiments, ${ }^{*}=p<0.05,{ }^{* *}=p<0.001$ vs non-treated control. 

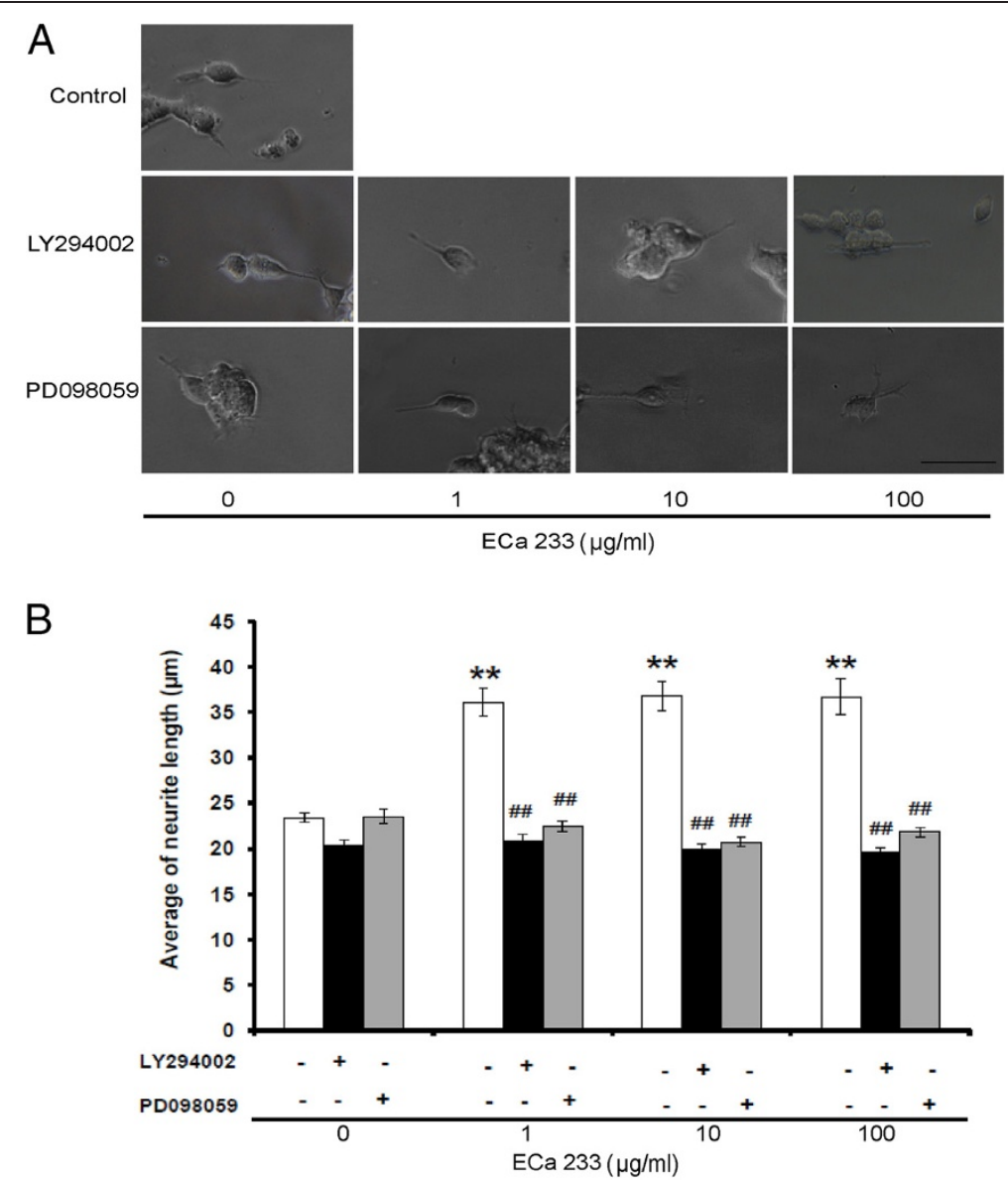

Figure 5 Representative photomicrograph of IMR-32 cells. (A) after pre-treated with LY294002 or PD098059 in the presence or absence of ECa $233(1,10$ and $100 \mu \mathrm{g} / \mathrm{ml}$ ) (scale bar $=50 \mu \mathrm{m}$ ). (B) Morphometric analysis of the cell treated with LY294002 or PD098059 on the increment of neurite outgrowth induced by ECa 233. Neurites from 60 living cells per treated condition were evaluated, $(n=3)$. Data are presented as mean \pm S.E., ${ }^{* *}=p<0.001$ vs non-treated control. ${ }^{\# \#}=p<0.001$ vs ECa 233 treated groups.

\section{Discussion}

Although the plant originated extracts have garnered attentions as important sources of drugs and health products, the inconsistency of main components found in such extracts limits their use as well as further development to clinical use. Establishment of standardized extract with consistency of its bioactive constituents could enhance reproducible biological responses and subsequently reliable use of herbal products [21]. Based on well-defined constituents and numbers of scientific evidence, EGb 761, a standardized extract of Chinese ancient plant, Ginko biloba, known as a brain tonic remedy, has been prescribed for memory deficit all over the world [22]. By the same analogy, C. asiatica which has long been used in Ayurveda to enhance memory was extensively investigated [23]. In an attempt to make a reliable herbal product, ECa 233, a standardized extract of C. asiatica, was established and investigated for its effect on brain function. We have found that ECa 233 could attenuate memory deficit and exerted anxiolytic effect in animal models [16-18]. As administration of fresh leaf juice of $C$. asiatica was found to enhance dendritic aborization of hippocampal and amygdala neurons in neonatal and adult rats [24-27], we hypothesized that ECa 233 might enhance neurite outgrowth.

As expected, the present study clearly demonstrated neuritogenic effect of ECa 233 in the range of 1-100 $\mu \mathrm{g} / \mathrm{ml}$. Further experiment was then conducted to gain an insight into signaling pathways possibly involved. Numerous signaling pathways involving in neurite outgrowth have been proposed [2,5]. Among them, ERK and Akt activations have long been known to be important for neurite elongation induced by certain neurotrophic factors including NGF $[28,29]$, neurotrophin-3 (NT-3) [30], BDNF [31] as well as natural compounds including FK506 [32,33], genipin [34], honokiol [4] and militarinone A [9]. In addition, ginsenoside, triterpenoidglycoside from gingseng, has been shown to significantly increase the neurite outgrowth of neuroblastoma cells [35]. 
In line with the findings previously demonstrated by some other natural products mentioned above, western blot analysis demonstrated that administration of $\mathrm{ECa}$ 233 significantly increased the level of phosphorylated ERK and Akt in IMR-32 cells indicating their activation in the presence of ECa 233. In addition, contribution of ERK and Akt signaling pathways was subsequently confirmed by the results that the neurite outgrowth promoting effect of ECa 233 was abolished by specific inhibitors of MEK (PD098059) or PI3K (LY294002) suggesting that ECa 233 promoted neurite outgrowth in human neuroblastoma IMR-32 cells via MEK/ERK and PI3K/Aktdependent mechanisms. Though, asiatic acid, one of chemical constituents present in C. asiatica has been proposed to elicit its effect via MAP kinase pathway [12], increases of phosphorylated ERK and Akt observed in the present study are likely to be attributable to madecassoside and/or asiaticoside, the major constituents of ECa 233.

In agreement with the fact that $C$. asiatica is widely consumed as food, ECa 233 in the concentrations that promoted neurite outgrowth in human neuroblastoma IMR-32 cells had no effect on cell viability under the experimental condition indicating safety of ECa 233, a standardized extract derived from C. asiatica. Similarly, safety profiles of ECa 233 have been previously reported in both acute and sub-chronic toxicity testing. Oral administration of ECa 233 in the dose up to $10 \mathrm{~g} / \mathrm{kg}$ did not cause any lethality and no significant adverse effects was observed in experimental animals receiving daily administration of ECa 233 in the dose range of 10$1000 \mathrm{mg} / \mathrm{kg} /$ day [36]. In consideration to very favorable safety profiles and significant in vivo neuroprotective activity of ECa 233 [18], the results of the present study supports further development of ECa 233 for neuronal injury as well as neurodegenerative diseases in human.

\section{Conclusions}

The present study demonstrated the neurite outgrowth promoting activity of ECa 233 in human IMR-32 neuroblastoma cell line. The neuritogenic effect observed seemed to be mediated via ERK1/2 and Akt signaling pathways. The results obtained support potential benefit of ECa 233 for the management of neuronal injury and neurodegenerative diseases. Further pharmacodynamic and pharmacokinetic studies of ECa 233 are needed to bring ECa 233 into clinical use.

\footnotetext{
Abbreviations

C. asiatica: Centella asiatica; MEK: Mitogen activated protein kinase; ERK: Extracellular signaling regulated kinase; PI3K: Phosphoinositide-3-kinase; NGF: Nerve growth factor; BDNF: Brain derived neurotrophic factor; NT-3: Neurotrophin-3; PD: PD 098059; LY: LY 294002.
}

\section{Competing interests}

All authors declare that they have no competing interests.

\section{Authors' contributions}

OW participated in design and conducting the experiments, analysis of data, drafting the manuscript. VP, PrC and AW participated in technical supports and interpretation of the data. AV and BT supervised, design of experiments, analyzed and interpretation of the data. PiC was a coordinator, designed the study, analysis and interpretation of data, and drafting the manuscript. MT supervised, conceived and designed the experiment, interpretation of the data and revision of the manuscript. All authors have read and approved the final manuscript.

\section{Acknowledgements}

The work was supported by The $90^{\text {th }}$ Anniversary of Chulalongkorn University Fund (Ratchadaphiseksomphot Endowment Fund) and Ratchadaphiseksomphot Endowment Fund for Cell-based Drug and Health Product Development Research Unit. The authors would like to thank Associate Professor Ekarin Saifah and collaborates for the provision of ECa 233.

\section{Author details}

${ }^{1}$ Inter-disciplinary Program in Physiology, Graduate School, Chulalongkorn University, Bangkok 10330, Thailand. ²Department of Pharmacology and Physiology, Faculty of Pharmaceutical Sciences, Chulalongkorn University, Bangkok 10330, Thailand. ${ }^{3}$ Cell-based Drug and Health Product Development Research Unit, Chulalongkorn University, Bangkok 10330, Thailand. ${ }^{4}$ Faculty of Dentistry, Mahidol University, Bangkok 10400, Thailand. ${ }^{5}$ Department of Physiology, Phramongkutklao College of Medicine, Bangkok 10400, Thailand. ${ }^{6}$ Faculty of Pharmacy, Silpakorn University, Nakonprathom 73000, Thailand. ${ }^{7}$ Faculty of Pharmaceutical Scienccs, Burapha University, Chonburi 20131, Thailand.

Received: 1 March 2013 Accepted: 31 July 2013

Published: 4 August 2013

\section{References}

1. Plachez C, Richards LJ: Mechanisms of axon guidance in the developing nervous system. Curr Top Dev Biol 2005, 69:267-346.

2. Kaplan D, Miller F: Neurotrophin signaling transduction in the nervous system. Curr Opin Neurobiol 2000, 10:381-391.

3. Hur J, Lee P, Kim H, Kang I, Lee KR, Kim SY: (-)-3,5-Dicaffeoyl-muco-quinic acid isolated from Aster scaber contributes to the differentiation of PC12 cells: through tyrosine kinase cascade signaling. Biochem and Biophys Res Commun 2004, 313:948-953.

4. Zhai H, Nakade K, Oda M, Mitsumoto Y, Akagi M, Sakurai J, Fukuyama Y: Honokiol-induced neurite outgrowth promotion depends on activation of extracellular signal-regulated kinases (ERK1/2). Eur J Pharmacol 2005, 516:112-117.

5. Read DE, Gorman AM: Involvement of Akt in neurite outgrowth. Cell Mol Life Sci 2009, 66:2975-2984.

6. Takahashi K, Piao S, Yamatani H, Du B, Yin L, Ohta T, Kawagoe J, Takata K, Tsutsumi S, Kurachi H: Estrogen induces neurite outgrowth via Rho family GTPases in neuroblastoma cells. Mol Cell Neurosci 2011, 48:217-224.

7. Labelle C, Leclerc N: Exogenouse BDNF, NT-3 and NT-4 differentially regulate neurite outgrowth in cultured hippocampal neurons. Brain Res Dev Brain Res 2000, 123:1-11.

8. Chao MV, Rajagopal R, Lee FS: Neurotrophin signaling in health and disease. Clin Sci (Lond) 2006, 110:167-173.

9. Küenzi P, Kiefer S, Koryalina A, Hamburger M: Promotion of cell death or neurite outgrowth in PC-12 and N2a cells by the fungal alkaloid militarinone A depends on basal expression of p53. Apoptosis 2008, 13:364-376.

10. Wang X, Wang Z, Yao Y, Li J, Zhang X, Li C, Cheng Y, Ding G, Liu L, Ding Z: Essential role of ERK activation in neurite outgrowth induced by a-lipoic acid. Biochim Biophys Acta 1813, 2011:827-838.

11. Horner PJ, Gage FH: Regenerating the central nervous system. Nat 2000, 407:963-970.

12. Soumyanath A, Zhong YP, Gold SA, Yu X, Koop DR, Bourdette D, Gold BG: Centella asiatica accelerates nerve regeneration upon oral administration and contains multiple active fractions increasing neurite elongation in-vitro. J Pharm Pharmacol 2005, 57:1221-1229.

13. Maier IC, Schweb ME: Sprouting, regeneration and circuit formation in the injured spinal cord: factors and activity. Philos Trans R Soc Lond B Biol Sci 2006, 61:1611-1634. 
14. Brinkhaus B, Lindner M, Schuppan D, Hahn EG: Chemical, pharmacological and clinical profile of the East Asian medical plant Centella asiatica. Phytomedicine 2000, 7:427-448.

15. Inamdar PK, Yeole RD, Ghogare AB, de Souza NJ: Determination of biologically active constituents in Centella asiatica. J Chromatography A 1996, 742:127-130.

16. Wanasuntronwong A, Tantisira MH, Tantisira B, Watanabe H: Anxiolytic effects of standardized extract of Centella asiatica (ECa 233) after chronic immobilization stress in mice. J Ethnopharmacol 2012, 143:579-585.

17. Tantisira MH, Tantisira B, Patarapanich C, Suttisri R, Luangcholatan S, Mingmalailak S, Wanasuntronwong A, Saifah E: Effects of standardized extract of Centella asiatica ECa 233 on learning and memory impairment induced by transient bilateral common carotid artery occlusion in mice. Thai J Pharmacol 2010, 32:22-33.

18. Kam-eg A, Tantisira B, Tantisira MH: Preliminary study on effects of standardized extract of Centella asiatica, Eca 233, on deficit of learning and memory induced by an intracerebroventricular injection of $\beta$-amyloid peptide in mice. Thai J Pharmacol 2009, 31:79-82.

19. Fukuyama Y, Nakade K, Minoshima Y, Yokoyama R, Zhai H, Mitsumoto Y: Neurotrophic activity of honokiol on the cultures of fetal rat cortical neurons. Bioorg Med Chem Lett 2002, 12:1163-1166.

20. Hur J, Lee P, Moon E, Kang I, Kim SH, Oh MH, Kim Y: Neurite outgrowth induced by spicatoside $A$, a steroidal saponin, via the tyrosine kinase $A$ receptor pathway. Eur J Pharmacol 2009, 620:9-15.

21. Taylor JLS, Rabe T, McGaw LJ, Jäger AK, Staden Van J: Toward the scientific validation of traditional medicinal plants. Plant Growth Regul 2001, 34:23-37.

22. Eckert GP: Traditional used plants against cognitive decline and alzheimer disease. Front Pharmcol 2010, 1:1-10.

23. Wattanatorn J, Mator L, Muchimapura S, Tongun T, Pasuriwong O, Piyawatkul N, Yimtae K, Sripanidkulchai B, Singkhoraard J: Positive modulation of cognition and mood in the healthy elderly volunteer following the administration of Centella asiatica. J Ethnopharmacol 2008, 116:325-332.

24. Rao SB, Chetana M, Uma Devi P: Centella asiatica treatment during postnatal period enhances learning and memory in mice. Physiol Behav 2005, 86:449-457.

25. Mohandas Rao KG, Muddanna Rao S, Gurumadhva Rao S: Centella asiatica (L.) Leaf extract treatment during the growth spurt period enhances hippocampal CA3 neuronal dendritic arborization in rats. Evid Based Complement Alternat Med 2006, 3:349-357.

26. Mohandas Rao KG, Muddanna Rao S, Gurumadhva Rao S: Enhancement of amygdaloid neuronal dendritic arboritezation by fresh leaf juice of Centella asiatica (Linn) during growth spurt period in rats. Evid Based Complement Alternat Med 2009, 6:575-611.

27. Gadahad MR, Rao M, Rao G: Enhancement of hippocampal CA3 neuronal dendritic arboritezation by Centella asiatica (Linn) fresh leaf extract in adult rats. J Chin Med Assoc 2008, 71:6-13.

28. Boglari G, Szeberenyi J: Nerve growth factor in combination with second messenger analogues causes neuronal differentiation of PC12 cells expressing a dominant inhibitory Ras protein without inducing activation of extracellular signal- regulated kinases. Eur J Neurosci 2001, 14:1445-1454

29. Tsuji M, Inanami O, Kuwabara M: Induction of neurite outgrowth in PC12 cells by alpha-phenyl-N-tert-butylnitron through activation of protein kinase $C$ and the ras-extracellular signal-regulated kinase pathway. J Biol Chem 2001, 276:32779-32785.

30. Aletsee C, Beros A, Mullen L, Palacios S, Pak K, Dazert S, Ryan AF: Ras/MEK but not p38 signaling mediates NT-3-induced neurite extension from spiral ganglion neurons. J Assoc Res Otolaryngol 2001, 2:377-387.

31. Bosco A, Linden R: BDNF and NT-4 differentially modulate neurite outgrowth in developing retinal ganglion cells. J Neurosci Res 1999, 15:759-769.

32. Price RD, Yamaji T, Matsuoka N: FK506 potentiates NGF-induced neurite outgrowth via the Ras/Raf/MAP kinase pathway. J Pharmacol 2003, 140:825-829.

33. Gold BG, Zhong YP: FK506 requires stimulation of the extracellular signal regulated kinase $1 / 2$ and the steroid receptor chaperone protein p23 for neurite elongation. Neurosignals 2004, 13:122-129.
34. Yamazaki M, Chiba K, Mohri T, Hatanaka H: Cyclic GMP-dependent neurite outgrowth by genipin and nerve growth factor in PC12h cells. Eur J Pharmacol 2004, 488:35-43.

35. Rudakewich M, Ba F, Benishin CG: Neurotrophic and neuroprotective action of Ginsenosides Rb1 and Rg1. Planta Med 2000, 67:533-537.

36. Chivapat $\mathrm{S}$, Chavalittumrong $\mathrm{P}$, Tantisira $\mathrm{MH}$ : Acute and sub chronic toxicity studies of a standardized extract of Centella asiatica ECa 233. Thai J Pharm Sci 2011, 35:55-64.

doi:10.1186/1472-6882-13-204

Cite this article as: Wanakhachornkrai et al:: Neuritogenic effect of standardized extract of Centella asiatica ECa233 on human neuroblastoma cells. BMC Complementary and Alternative Medicine 2013 13:204

\section{Submit your next manuscript to BioMed Central and take full advantage of:}

- Convenient online submission

- Thorough peer review

- No space constraints or color figure charges

- Immediate publication on acceptance

- Inclusion in PubMed, CAS, Scopus and Google Scholar

- Research which is freely available for redistribution 